\title{
Vladimir Grigorevich Lukonin (1932-1984)
}

\author{
Richard N. Frye
}

The death of the director of the Oriental section (Otdel Vostok) of the Hermitage Museum of Leningrad in September 1984 was not only a grievous loss to his colleagues in the Soviet Union but a great shock to friends all over the world.

Volodya was born in Leningrad in 1932; he studied at Leningrad University, graduating in 1955, and continued his research in the Hermitage where he defended his candidate dissertation (equivalent to a doctorate) in 1961 on "Iran in the Third to Fourth Centuries--The Origin of the Sasanian State and the Formation of an Official Style in Art." In his summary of the thesis he showed the future direction of his research with a rare combination of historical, numismatic, and artistic skills. He showed that, although the early coins of Ardashir were a direct continuation of the Frataraka coins of Persis, later a new style was initiated by the first Sasanian and this became manifest in the art of seals, silver vessels, and elsewhere. A series of articles in the Vestnik Drevnei Istorii and Epigrafika Vostoka elucidated the confused period of history leading to the accession to the throne of Narseh, including Sasanian conquests in the east and Kushano-Sasanian coins. Lukonin created the term Kushano-Sasanian for coins of Sasanian governors in the east based on Kushan typology, while Sasano-Kushan he used for coins of Sasanian style.

He is best known in the West for his book in English Persia II, in the series Archaeologica Mundi published in Geneva in 1967 where new Sasanian works of art are presented. His catalogue of the Sasanian gems, completing the work of A. Borisov (Leningrad, 1963), is a valuable contribution to Sasanian seal inscriptions as well as ancient glyptics, while several articles on individual gems are also noteworthy. In his work on Sasanian bullae, or clay sealings, his theory that the impressions of seals on them represented, on the whole, merchants indicating their ownership of shares 
of the merchandise sealed is now widely accepted by scholars in the field.

Always eager to propose new theories or views, perhaps his most important work is his book Iran in the Third Century, New Materials and an Attempt at Reconstruction (Moscow, 1979) with a long English summary, in which he summed up his past work, analyzing the investiture scenes on the early Sasanian rock carvings with a number of new ideas on the interpretations of various carvings. EspecialIy valuable is his detailed analysis of the coins of Bahram II and his reconstruction of events based on Narseh's inscription of Paikuli, the coins and art objects.

This brief summary of the work of Lukonin, student of $J$. Orbeli and $K$. Trevor, and successor to the latter, touches only on his published writings. His work in the museum organizing exhibitions, as well as helping students and colleagues, is known only to those who knew him well or worked with him. Always generous with his knowledge and never hiding new finds, Volodya was a wonderful friend and colleague. He traveled to Western Europe, to the United States, and several times to Iran. He was internationally known and respected, and he was not only the leader of the Oriental section of the Hermitage but a member of the delightful band of Iranists of Leningrad. I first met Volodya in 1955, and over the years, on my many trips to the Soviet Union or to Iran, I never failed to see him and his colleagues. His last book. I believe, was the excellent work on the culture and economy of ancient Iran written with Muhammad Dandamaev (Moscow, 1980), soon to appear in English translation.

Volodya leaves behind a son and a grandson. Ever generous, he must have had a premonition of the end already in the summer of 1984 at the Assyriological rencontre in Leningrad, for he gave away to foreign friends some of his cherished mementos. I wept unashamedly at the news of his death. Leningrad in the 1960s and 1970s was a Cameiot of Oriental studies, and let us hope that such camaraderie, such lively interest in scholarship, such love of life will always serve as a model of the best in man. Volodya was part of it.

Richard N. Frye 